\title{
Preface: Teaching reason and the unreasonable
}

\section{Michael H. Morris and Eric Liguori}

\section{FROM EMERGENCE TO INSTITUTIONALIZATION}

As we publish the second volume of the Annals of Entrepreneurship Education and Pedagogy, levels of innovation in how entrepreneurship is taught, and what is taught, are unprecedented. The emergence of entrepreneurship within universities over the past 30 years has been breathtaking (Greene and Rice, 2007; Hills, 1988; Kuratko, 2005; Neck and Greene, 2011). It is not unusual at major institutions to find formal degree programs at the undergraduate and graduate levels (i.e., entrepreneurship majors, minors, concentrations, certificates, master's degrees and $\mathrm{Ph} . \mathrm{D}$. programs), a curriculum with 20 or more courses, a portfolio of co-curricular programming, and a broad mix of community engagement initiatives (Katz, 2003; Morris et al., 2013a). From a handful of programs three decades ago, today there are more than 3000 institutions offering entrepreneurship programs. The growth is likely to continue in the coming decades, as across the globe we find the twenty-first century to be the century of the entrepreneur.

Patterns in the emergence of entrepreneurship education are summarized in Table I.1. We see dramatic change as a formal discipline has taken shape, a considerable volume of high-quality research has appeared, and diverse and innovative programs of study have been established. Entrepreneurship's position within the university has been "institutionalized" as structures have been modified to include not only institutes and centers, but also academic co-departments, departments and schools of entrepreneurship. Universities are employing tenure-track faculty in entrepreneurship, and these faculty members are able to focus exclusively on teaching, researching and performing service in entrepreneurship. Meanwhile, the scope of these programs has been extended across the campus, into the community and across the globe. Program leaders are introducing novel approaches to staffing, funding, and economic engagement with the society (Morris et al., 2013a). In the process, they are able to 


\title{
Table I.1 Emergence of entrepreneurship education
}

\author{
Relative emphasis: sidelight $\rightarrow$ sub-area $\rightarrow$ area $\rightarrow$ major discipline \\ Curriculum: courses $\rightarrow$ structured curriculum $\rightarrow$ undergraduate degrees \\ graduate degrees
}

Structure: based in existing academic unit $\rightarrow$ based in center or institute $\rightarrow$ creation of co-department of entrepreneurship $\rightarrow$ creation of separate departments and schools of entrepreneurship

Funding model: cost center $\rightarrow$ revenue center $\rightarrow$ profit center

Outreach: campus-based events $\rightarrow$ community and campus events $\rightarrow$ integration of curriculum and outreach

Assurance of learning: course evaluations $\rightarrow$ venture metrics $\rightarrow$ competencies $\rightarrow$ integrative model

Faculty: adjuncts $\rightarrow$ shared faculty $\rightarrow$ dedicated faculty $\rightarrow$ joint appointments

Research: little scholarly activity $\rightarrow$ core faculty publishing $\rightarrow$ stimulation of interdisciplinary research agendas

Focal market: business school $\rightarrow$ local community $\rightarrow$ campus $\rightarrow$ region $\rightarrow$ nation/globe

Purpose: fill a gap $\rightarrow$ develop area of study $\rightarrow$ empower students and create ventures $\rightarrow$ transform campuses and communities

Philosophy: help students learn about venture creation $\rightarrow$ create ventures $\rightarrow$ think and act entrepreneurially

Source: Adapted from Morris et al. (2013a).

generate significant resources for universities, while also playing a central role in a movement toward establishing the "entrepreneurial university" (Clark, 2004; Gibb and Hannon, 2006).

It could be argued that this growth and expansion has exposed tens of thousands of students to entrepreneurial possibilities, given young entrepreneurs a set of tools and concepts that can enhance their likelihood of success, and encouraged the development of ecosystems to support an entrepreneurial community, while fostering (an unclear level of) start-up activity. Yet the case could also be made that the emergence 
of entrepreneurship education has occurred so rapidly that it has outpaced our understanding of what should be taught by entrepreneurship educators, how it should be taught and how outcomes should be assessed.

\section{WHERE ARE THE GAPS?}

A gap exists between a growing demand for and the available supply of entrepreneurship education. On the supply side, we also confront gaps in our understanding regarding how best to design and deliver these educational programs. Examples of some of the major issues include:

- defining the field's core content or substance and its boundaries;

- the structure and flow of an entrepreneurship degree program;

- teaching techniques that are most effective for various content elements;

- best practices in classroom innovation;

- the role and extent of experiential learning and deliberate practice in an entrepreneurship program;

- the relative effectiveness of differing educational delivery mechanisms;

- implications of different learning approaches for how entrepreneurship is taught;

- appropriate learning outcomes and standards; and

- relevant assurance of learning measures when it comes to entrepreneurship.

Although scholarly research in entrepreneurship has been greatly expanded, the volume of substantive research focused on issues related to education and pedagogy has been limited (Katz, 2003; Morris, 2014). Similarly, few attempts have been made to document effective and ineffective practices in the classroom, or measure the relationship between course or program design and delivery approaches and tangible outcomes from entrepreneurship programs (Solomon et al., 2002).

It is also possible that these gaps will get greater. Entrepreneurship education is not static. It represents a moving target, with continuous additions to both the depth and the breadth of the content of the discipline (DeTienne and Chandler, 2004; Gorman et al., 1997). Meanwhile, entrepreneurship programs are emerging as innovation platforms (Honig, 2004). They are continually spinning off a fascinating array of new courses, pedagogies, student support programs and outreach initiatives. Further, new learning platforms, technologies and vehicles are appearing for enhancing how entrepreneurship is taught. In addition, the student 
audience for entrepreneurship education is global, and not only continues to grow in size but also is becoming more diverse, as reflected in the age, gender, life stage, ethnicity, professional background, motives and contexts of those wishing to better understand entrepreneurship in all of its manifestations.

\section{WHAT SHOULD WE BE TEACHING?}

Part of the challenge in establishing what is taught in the entrepreneurship classroom concerns who is doing the teaching and where the teaching is taking place. Courses today are being taught by full-time dedicated faculty members (some with degrees in entrepreneurship and most with degrees in other disciplines), faculty who primarily teach in other disciplines but find themselves teaching an entrepreneurship course, professors of practice and adjunct faculty who have strong commercial backgrounds, and others. This tendency alone can lead to wide differences in knowledge, beliefs and attitudes regarding what should be taught. Courses are taught both inside and outside business schools, which can also influence content.

The focus of entrepreneurship education would seem to include three general areas of emphasis, as summarized in Table I.2. The first area might be labeled "business basics," or how the different functional areas of business apply in an early stage venture context. One might question the extent to which entrepreneurship, approached as business basics, represents a unique discipline with its own defined content, as opposed to a field of study that relies on teaching borrowed content from such fields as management, psychology, sociology, anthropology, physics and ecology. The second area of focus might be termed "entrepreneurship basics," where core content from the emerging discipline is emphasized. Examples of topical issues here include the entrepreneurial process, innovative business models, lean start-ups, entrepreneurial orientation and entrepreneurial cognition, among others. The third focal area is the entrepreneurial mindset and its associated mix of entrepreneurial competencies. Here, educators focus on helping students develop their abilities in such areas as opportunity recognition and assessment, conveying a compelling vision, leveraging resources, mitigating risks, and engaging in guerrilla behavior (Morris et al., 2013b).

Arguably, the greatest promise lies within columns two and three in Table I.2. Business schools already teach business basics, effectively lessening the need for this type of entrepreneurship education. Approached as business basics, new ventures simply represent another context for managerial action, as opposed to a distinct discipline with a unique subject 
Table I.2 What should be the focus of our teaching?

\begin{tabular}{lll}
\hline Business basics & Entrepreneurship basics & $\begin{array}{l}\text { Entrepreneurial } \\
\text { mindset and } \\
\text { competencies }\end{array}$ \\
\hline Setting up the books & Entrepreneurship defined & Opportunity alertness \\
How to sell & Entrepreneurial process & Risk mitigation \\
Hiring of staff & Characteristics of & Resource leveraging \\
Forms of enterprise & entrepreneurs & Conveying a \\
Cash flow management & Types of entrepreneurs & compelling vision \\
Formulating strategy & Contexts for entrepreneurship & Value innovation \\
Market analysis & Innovative business models & Passion \\
Setting up operations & Entrepreneurial cognition & Persistence and tenacity \\
Pricing & Nature of opportunity & Creative \\
Promotion and & Opportunity discovery & problem-solving \\
advertising & or creation & Guerrilla behavior \\
Financial statements & Seed and venture capital & Optimism \\
Franchising & Lean start-up & Learning from failure \\
Management control & Entrepreneurial orientation & Implementing change \\
Cost analysis & Entrepreneurship and & Adaptation \\
Protecting intellectual & society & Resilience \\
property & Exit strategies & Building and using \\
& Ethical challenges in & networks \\
& entrepreneurship & \\
\hline
\end{tabular}

matter. Entrepreneurship education must involve more than the mechanics of business start-up. The real potential lies in uncovering ways to promulgate the entrepreneurial mindset, and foster understanding regarding how to recognize and exploit opportunity in a wide variety of contexts.

\section{TEACHING THE UNREASONABLE}

The core precept guiding our pedagogical approaches should be the idea that entrepreneurship is about empowerment and transformation. We are encouraging students to create their own futures and futures for those around them. We want them to transform markets, industries, communities and economies. We are teaching them to be somewhat unreasonable, challenge norms and be disruptive. Yet, as we teach students to challenge assumptions, think in bold innovative terms, identify and leverage the resources of others, and persist in creatively overcoming obstacles, we must also teach them to approach entrepreneurial action from a perspective of structure, rigor, logic and realism. In this sense then, entrepreneurship 
education represents the confluence of unreasonable thinking and focused discipline.

Accordingly, educators are engaged in a balancing act. They must provide the tools and perspectives that enable students to think in bigger terms and challenge them to imagine truly novel value propositions that lead customers, create markets and transform the competitive landscape. Yet they must be vigilant in teaching and applying the frameworks and principles that bring rigor, logic and realism to student thinking and acting.

Achievement of this balance can be facilitated by pedagogical approaches built around three pillars: content-based education, competency-based education and experientially based education. With regard to content, there is a rich and growing knowledge base surrounding the entrepreneurial process and the requirements for entrepreneurial action available for educators (column two in Table I.2). Yet available teaching resources, including textbooks, tend to emphasize business basics (column one in Table I.2). In terms of competencies, Morris and colleagues (2013b) have generated a set of 13 core entrepreneurial competencies, together with guidance in how to teach and measure progress on each of them (see also DeTienne and Chandler, 2004; Fiet, 2001). Finally, a large percentage (perhaps as much as 60 percent) of the education program should center on experiential learning, or what Neck et al. (2014) label "deliberate practice." More than just case studies or business plans, the experiential dimension of education places students into their discomfort zones, forces them to think and act under conditions of ambiguity, introduces vexing obstacles, includes real elements of risk and rewards tenacity, adaptation and creative problem-solving (see also Solomon et al., 2002).

\section{ORGANIZATION OF THE $A N N A L S$}

The Annals of Entrepreneurship Education and Pedagogy, published in partnership with the United States Association for Small Business and Entrepreneurship (USASBE), aims to identify and revisit some of the most important and provocative work generated through USASBE's annual conference and associated programs. Specifically, the editorial board of the Annals is charged with systematically identifying the most important papers, presentations and workshops that have appeared at USASBE during the past 30 years, and then contacting and working with the authors and presenters of this work to produce updated perspectives. The intent is that they capture the richest insights and best practices in teaching entrepreneurship, building entrepreneurship curricula, and developing educational programs. 
The Annals is organized into three parts. In Part I, we open with perspectives from five master educators regarding what each has learned from teaching entrepreneurship for at least a decade (Chapter 1). This is then followed by 14 research chapters that reflect some of the "big issues" in entrepreneurship education. The lead chapter by Jeffrey Stamp (Chapter 2) explores how to teach creativity, a topic woven throughout most entrepreneurship programs, and often featured as a stand-alone course. Albornoz and Amorós (Chapter 3) then empirically assess the effects of entrepreneurship education, including its role in changing intentions versus developing competencies within students. The need to move toward a more competency-based approach to education is stressed by White, Hertz and Moore (Chapter 6). Grossman (Chapter 5) examines the huge popularity of the lean start-up methodology among entrepreneurship educators, while also raising some potential concerns. Rosenthal (Chapter 7) provides rich insights on using the case method when teaching entrepreneurship. Issues in experiential learning are the themes of a number of chapters. Schindehutte and Morris (Chapter 8) discuss the value of having students build experience portfolios; Morland and Thompson (Chapter 10) explore the implications for various stakeholders of degree programs centered on actual venture creation; Clouse and colleagues (Chapter 12) report on an applied research curriculum design to infuse entrepreneurial thinking into authentic problem-based learning environments across disciplines; and Pryor (Chapter 11) investigates the challenges of incorporating experiential learning when teaching large mass sections. In a related vein, Bruton (Chapter 9) provides a lens on the importance of critique and self-assessment in product and business design processes, proposing a model for articulating and framing the skills students require to successfully come up with viable ideas. How the student thinks is the concern of Santos and colleagues (Chapter 4) in their examination of the research on entrepreneurial cognition and its implications for educational efforts. Tools for use in entrepreneurship-related courses also receive attention. Morris (Chapter 13) introduces a framework that can used at the front end, or analytical stage, of consulting courses, while Markin and colleagues (Chapter 14) explain how the Architecture, Governance, Entrepreneurship and Stewardship (A-GES) framework can be used in a family business course. At a more macro level, Hechavarria and colleagues (Chapter 15) note the growing interest in entrepreneurial ecosystems, assessing the role universities can and should be playing in their development.

Part II of the Annals features five model academic programs in entrepreneurship: the University of Southern California (Chapter 16), Lancaster University (Chapter 17), Baylor University (Chapter 18), the University of Maryland (Chapter 19) and Syracuse University (Chapter 20). These 
schools were selected based on the recognition they have received from various sources, most notably the National Model Entrepreneurship Program Awards coordinated by USASBE each year. We have prioritized programs that we believe have had a significant impact on the advancing entrepreneurship education at the tertiary level. Programs were also selected to provide a representation of different types of university environments. Importantly, while each program is outlined in fairly comprehensive terms, the reader will detect a unique theme or focal aspect embedded in the programs of each of these five universities.

In Part III, we provide a collection of 11 leading edge examples of teaching innovations, unique approaches to experiential learning, and high-impact community engagement initiatives. Many of these initiatives have also won awards or recognition both from USASBE and from other prominent organizations and groups. Each of them has been selected based not only on its innovativeness and the proven results it has produced, but also because of its potential for replication and adaptation at other institutions. Moreover, the initiatives that are featured reflect innovations at both the undergraduate and graduate levels, inside and outside the business school, on-campus and off-campus, and that emphasize economic and social outcomes.

Entrepreneurship is experiencing growing pains as it continues to emerge and becomes a mainstay in the modern university. We believe the discipline is uniquely positioned not only to empower and transform students, but to empower and transform higher education. Entrepreneurship educators are poised to shed new light on interdisciplinary approaches to teaching, uncover entirely new methods for experiential learning and the design of curricula around experiences, and create new ways for universities to engage society and connect such engagement to the learning process. A key to fulfilling this promise is that we learn much more about how entrepreneurship should be taught and how educational programs should be designed. We hope this second volume of the Annals makes a contribution to bridging the significant gaps in our understanding that remain.

Michael H. Morris, University of Florida, USA

Eric Liguori, University of Tampa, USA

\section{REFERENCES}

Clark, B.R. (2004), Delineating the character of the entrepreneurial university, Higher Education Policy, 17(4), 355-370.

DeTienne, D.R. and Chandler, G.N. (2004), The role of gender in opportunity identification, Entrepreneurship Theory and Practice, 31(3), 365-386. 
Fiet, J.O. (2001), The pedagogical side of entrepreneurship theory, Journal of Business Venturing, 16(2), 101-117.

Gibb, A. and Hannon, P. (2006), Towards the entrepreneurial university, International Journal of Entrepreneurship Education, 4(1), 73-110.

Gorman, G., Hanlon, D. and King, W. (1997), Some research perspectives on entrepreneurship education, enterprise education, and education for small business management: a ten-year literature review, International Small Business Journal, 15, 56-77.

Greene, P.G. and Rice, M.P. (2007), Entrepreneurship Education, Cheltenham, UK and Northampton, MA, USA: Edward Elgar.

Hills, G.E. (1988), Variations in university entrepreneurship education: an empirical study of an evolving field, Journal of Business Venturing, 3, 109-122.

Honig, B. (2004), Entrepreneurship education: toward a model of contingencybased business planning, Academy of Management Learning and Education, 3(3), $258-273$.

Katz, J.A. (2003), The chronology and intellectual trajectory of American entrepreneurship education, Journal of Business Venturing, 18(2), 283-300.

Kuratko, D.F. (2005), The emergence of entrepreneurship education: development, trends, challenges, Entrepreneurship Theory and Practice, 29(3), 577-598.

Morris, M.H. (ed.) (2014), Annals of Entrepreneurship Education and Pedagogy2014, Cheltenham, UK and Northampton, MA, USA: Edward Elgar.

Morris, M.H., Kuratko, D.F. and Cornwall, J.R. (2013a), Entrepreneurship Programs and the Modern University, Cheltenham, UK and Northampton, MA, USA: Edward Elgar.

Morris, M.H., Webb, J.W., Fu, J. and Singhal, S. (2013b), A competency-based perspective on entrepreneurship education: conceptual and empirical insights, Journal of Small Business Management, 51(3), 352-369.

Neck, H.M. and Greene, P.G. (2011), Entrepreneurship education: known worlds and new frontiers, Journal of Small Business Management, 49(1), 55-70.

Neck, H., Greene, P. and Brush, C. (2014), Practice-based entrepreneurship education using actionable theory, in M.H. Morris (ed.), Annals of Entrepreneurship Education and Pedagogy, Cheltenham, UK and Northampton, MA, USA: Edward Elgar, pp. 3-20.

Solomon, G.T., Duffy, S. and Tarabishy, A. (2002), The state of entrepreneurship education in the United States: a nationwide survey and analysis, International Journal of Entrepreneurship Education, 1(1), 65-86. 